\title{
PERILAKU SEKSUAL MAHASISWA: STUDI DESKRIPTIF PADA SALAH SATU PERGURUAN TINGGI DI JATINANGOR
}

\author{
Fajar Syuderajat \\ Program Studi Ilmu Hubungan Masyarakat, Fakultas Ilmu Komunikasi, Universitas Padjadjaran
}

\begin{abstract}
ABSTRAK
Penelitian tentang perilaku seksual mahasiswa yang dilaksanakan pada tahun 2013 ini, bertujuan untuk mengetahui: (1) seberapa banyak mahasiswa yang melakukan aktivitas seksual; (2) bentuk-bentuk aktivitas seksual yang dilakukan; (3) siapa yang terlibat dalam aktivitas seksual; (4) lokasi melakukan aktivitas seksual dan (5) kuantitas melakukan aktivitas seksual. Metode deskriptif adalah metode yang digunakan; sedangkan populasi mahasiswa tingkat pertama hingga keempat dengan rentang umur 18 hingga 24 tahun; penelitian dilakukan pada salah satu perguruan tinggi di Kecamatan Jatinangor, Kabupaten Sumedang, Jawa Barat. Melalui teknik stratified random sampling kemudian didapatkan responden berjumlah 100 mahasiswa. Pengumpulan data dilakukan melalui angket, wawancara dan observasi. Fakta penting yang muncul dalam penelitian, yaitu: (1) pada umumnya mahasiswa menyatakan pernah melakukan aktivitas seksual; (2) bentuk aktivitas seksual yang dilakukan secara berurut berdasarkan jumlah ialah kissing, necking, petting, intercourse dan masturbasi; (3) sebagian besar melakukan aktivitas seksual melibatkan pacar, sebagian kecil melibatkan teman, PSK, dan lainnya yaitu "pecun" (perempuan cuma-cuma) serta tetangga atau anak tetangga rumah maupun kos/kontrakan; (4) rumah menjadi salah satu tempat dimana biasanya aktivitas seks dilakukan, menyusul tempat kos/kontrakan, kampus, hotel/penginapan, mobil, bioskop, dan pantai atau tempat-tempat rekreasi lainnya; (5) aktivitas seksual dilakukan minimal 1 kali dalam seminggu (hampir setengahnya) bahkan ada yang melakukan setiap hari (sebagian kecil).
\end{abstract}

Kata-kata Kunci: perilaku seksual, seks pranikah, mahasiswa, mahasiswi, perguruan tinggi, Jatinangor.

\section{STUDENTS SEXUAL BEHAVIOR: DESCRIPTIVE STUDY AT ONE OF}

\section{THE HIGHER EDUCATION INSTITUTION IN JATINANGOR}

\begin{abstract}
Research on the sexual behavior of students conducted in 2013 is aimed to determine: (1) how many students who engage in sexual activity; (2) forms of sexual activity; (3) who is engaged in sexual activity; (4) the location of sexual activity, and (5) the quantity of sexual activity. The method used is descriptive method the population of the sample are first to fourth year students with age ranging from 18 to 24 years old; research was conducted at one of the Higher Education in the Sub-district Jatinangor, Sumedang, West Java. Through stratified random sampling technique, the population as respondent is required are 100 students. Data collecting is done through questionnaires, interviews and observations. The important fact that emerged in the study, namely: (1) in general, students states that they had sexual activity; (2) forms of sexual activity performed sequentially from the higher rate are kissing, necking, petting, intercourse and masturbation; (3) the majority of sexual activity involving a boy/girlfriend, a small portion involving friends, PSK (prostitute), and the other is "pecun" (promiscuous girl) as well as a neighbor or a neighbor's child or landlord's son/ daughter; (4) the house becomes one of the places where sexual activity is usually being carried out, followed by a boarding house / rent, campus, hotel / lodging, cars, cinema, and a beach or other recreational areas; (5) almost half of the populaton performed sexual activity at least 1 time a week with a small portion of them do it everyday.
\end{abstract}

Key words: sexual behavior, premarital sex, student of higher education, Jatinangor.

Korespondensi: Fajar Syuderajat, S.Sos, Program Studi Ilmu Hubungan Masyarakat, Fakultas Ilmu Komunikasi Universitas Padjadjaran, Jl. Raya Bandung-Sumedang Km.21.Email: fajarsyuderajat@gmail.com 


\section{PENDAHULUAN}

Perilaku seksual yang dilakukan oleh pasangan pranikah sudah bergeser. "...di era '60-'70an sangat jarang ditemukan fenomena perilaku seksual sampai dengan perilaku intercourse pranikah (Santrock: 2003). Namun kini pasangan pranikah sudah kian permisif terhadap perilaku seksual pranikah. Sebuah LSM yang bergerak di bidang kesehatan reproduksi remaja di Bandung yaitu Mitra Citra Remaja (MCR) melakukan survey pada tahun 2000 terhadap remaja usia 15-20 tahun tentang perilaku seksual remaja di kota Bandung. Hasil survey ini menyebutkan bahwa 37\% remaja setuju terhadap perilaku berciuman bibir, $16.32 \%$ setuju terhadap perilaku petting, dan sebagian kecil sisanya setuju terhadap intercourse (Nanang, 2000).

Sikap pasangan pranikah yang permisif terhadap perilaku seksual pranikah terlihat dari bentuk perilaku seksual yang mereka lakukan. Berdasarkan data Direktorat Remaja dan Perlindungan Hak-hak Reproduksi Badan koordinasi Keluarga Berencana Nasional (BKKBN) sedikitnya $63 \%$ atau 40,95 juta remaja di Indonesia mengaku pernah melakukan hubungan intim sebelum menikah (BKKBN, 2014). Di kota Bandung sendiri, lebih dari setengah jumlah remaja atau tepatnya $56 \%$ sudah melakukan perilaku seksual intercourse pranikah. Data ini diperoleh berdasarkan survei yang dilakukan oleh Perkumpulan Keluarga Berencana Indonesia (PKBI) Jabar pada bulan Juni 2008 di setiap kecamatan dengan sampel 100 orang remaja berusia 15-24 (Tribun Jabar, 2013).

Melakukan perilaku seksual pranikah membawa konsekuensi tertentu. Konsekuensi yang diterima lebih banyak berupa dampak negatif baik dari segi biologis, psikologis, dan sosial. Salah satu efek biologis akibat perilaku seksual pranikah adalah penyakit menular seksual. Berdasarkan survey pada tahun 2013, 36\% dari 5829 kasus HIV/AIDS penderita penyakit menular seksual adalah pelajar dan mahasiswa, 163/4 kasus diderita oleh remaja 15-19 tahun dan jika rentang umur diperpanjang menjadi 20-24 maka jumlahnya menjadi 754/120 (Ditjen PP\&PL, 2013)

Khusus bagi remaja puteri, perilaku seksual pranikah akan berdampak sangat berat dengan potensi terjadinya kehamilan yang tidak di- harapkan. Salah satu solusi yang dipilih oleh mereka yang hamil diluar nikah adalah aborsi. Ketua Perkumpulan Keluarga Berencana Indonesia (PKBI) Jawa Tengah dr. Hartono Hadisaputro, Sp.OG. menyatakan bahwa di Indonesia diperkirakan terdapat 2,5 juta kasus aborsi setiap tahunnya pada diskusi: Aborsi Aman dan Hak Reproduksi Perempuan di kantor PKBI Jateng (30/09/2013). (Suara merdeka, 2013). Tercatat pula 2558 kasus aborsi dan lebih dari setengahnya atau tepatnya $58 \%$ dari aborsi tersebut dilakukan oleh remaja putri berusia 15-24 tahun Selain dari persoalan norma, pada sisi yang lain aborsi berbahaya bagi kesehatan reproduksi remaja yang melakukannya.

Sedangkan bagi yang memilih untuk meneruskan kehamilan, dapat beresiko mengalami kematian pada saat melahirkan karena otot rahim belum cukup kuat untuk berkontraksi. Anak yang dikandungpun ikut menanggung beban. Kecenderungan bayi yang dilahirkan oleh ibu yang masih remaja akan mengalami masalah kesehatan, potensi tak diabaikan dan akhirnya tumbuh menjadi generasi penerus yang tidak sehat secara biologis maupun psikologis. Rasa bersalah dan malu bagi mereka yang hamil diluar nikah, berpotensi menimbulkan kecemasan dan depresi.

Norma sosial masyarakat pun memberikan sanksi sosial kepada mereka yang melakukan perilaku seksual pranikah terlebih jika yang bersangkutan hamil di luar nikah. Dengan terjadinya kehamilan yang tidak diharapkan, maka yang bersangkutan akan mendapatkan ejekan dan penolakan dari lingkungan bahkan keluarga karena dianggap mencemarkan nama baik keluarga. Di institusi pendidikan, perilaku seksual pranikah terlebih yang kemudian hamil dianggap sebagai pelanggaran moral. Pelanggaran moral ini diganjar oleh institusi dengan pemutusan hak belajar (sementara bahkan permanen). Hal tersebut pernah dilakukan oleh beberapa perguruan tinggi yang mahasiswanya kedapatan melakukan hubungan seksual pranikah, terkait penelitian ini, khususnya perguruan tinggi di Jatinangor.

Jatinangor adalah sebuah kecamatan di Kabupaten Sumedang, Provinsi Jawa Barat. Wilayah Kecamatan Jatinangor meliputi luas $26,2 \mathrm{Km}^{2}$ yang secara administratif terbagi kedalam 12 Desa, 56 Dusun, 128 RW dan 479 RT. Titik terendah di Jatinangor terletak 
di daerah Desa Cintamulya setinggi $675 \mathrm{~m}$ di atas permukaan laut (dpl), sedangkan titik tertingginya terletak di puncak Gunung Geulis setinggi $1.281 \mathrm{~m} \mathrm{dpl}$. Suhu udaranya tergolong sejuk yang rata-rata berkisar antara $20^{\circ}$ $\mathrm{C}$ pada malam hari dan $27^{\circ} \mathrm{C}$ di siang hari. Pada sensus tahun 2012, penduduk Jatinangor berjumlah 113.850. (BPS Kabupaten Sumedang: 2013).

Jatinangor juga merupakan tempat dimana terdapat empat perguruan tinggi aktif: Universitas Padjadjaran (Unpad), Institut Koperasi Indonesia (IKOPIN), dan Institut Pemerintahan Dalam Negeri (IPDN) serta Institut Teknologi Bandung (ITB). Pada satu sisi keberadaan perguruan tinggi tersebut mampu mendongkrak perekonomian namun pada sisi lain dapat memunculkan persoalan sosial hingga kriminal. Berkaitan dengan masalah penelitian ini, terdapat kejadian menggemparkan yaitu kasus pembuangan bayi laki-laki yang terbungkus kantong plastik bed cover. Bayi malang tersebut ditemukan di halaman sebuah tempat kos di Dusun Ciawi, pada hari Jumat 5 April 2013. Pelakunya adalah In (20) yang berstatus sebagai mahasiswi semester empat salah satu perguruan tinggi di Jatinangor. (Galamedia: 2013).

Atas uraian diatas, maka tujuan penelitian ini adalah untuk mengetahui: (1) seberapa banyak mahasiswa yang telah melakukan aktivitas seksual; (2) bentuk-bentuk aktivitas seksual yang dilakukan; (3) siapa yang terlibat dalam aktivitas seksual; (4) lokasi melakukan aktivitas seksual dan (5) kuantitas melakukan aktivitas seksual.

\section{METODE PENELITIAN.}

Metode yang digunakan dalam penelitian ini yaitu metode deskriptif. Metode deskriptif digunakan dalam penelitian yang memaparkan situasi atau peristiwa. "Penelitian ini tidak mencari atau menjelaskan hubungan, tidak menguji hipotesis atau membuat prediksi". (Rakhmat, 1999: 24).

Populasi penelitian adalah mahasiswa salah satu perguruan tinggi di Jatinangor yang terdaftar sebagai mahasiswa tahun pertama hingga keempat dengan rentang umur 18 hingga 24 tahun. Untuk menentukan sampel yang optimal digunakan rumus Yamane (Rakhmat,
1999: 82) dengan presisi kurang lebih 10\% dan populasi $\mathrm{N}=4919$. Maka jumlah sampel yang diambil sebagai berikutt:

$$
\begin{aligned}
\mathrm{n} & =\frac{\mathrm{N}}{\mathrm{N}(\mathrm{d})^{2}+1} \\
& =\frac{4919}{4919(0,1)^{2}+1} \\
& =\frac{4919}{4919(0,01)+1} \\
& =98,007 \text { atau dibulatkan menjadi } 100
\end{aligned}
$$
responden.

Teknik pengumpulan data yang digunakan dalam penelitian ini terdiri dari angket, wawancara, observasi, dan studi kepustakaan. Adapun data utama yang akan menjadi patokan dalam pembahasan analisis ini adalah data yang di peroleh dari hasil wawancara, angket dan observasi; sedangkan data-data yang diperoleh melalui studi kepustakaan digunakan sebagai data penunjang untuk memperdalam analisis.

Penafsiran data dilakukan dengan menggunakan pedoman penafsiran data yang dikemukakan oleh Supardi (1979: 20) dalam buku statistik, yaitu: $01 \%-25 \%=$ sebagian kecil; $26 \%-49 \%=$ hampir setengahnya; $50 \%=$ setengahnya; $51 \%-75 \%=$ sebagian besar; $76 \%$ - $99 \%$ = pada umumnya; dan $100 \%=$ seluruhnya.

\section{HASIL DAN PEMBAHASAN}

Sarwono (2010) memberikan definisi perilaku seksual sebagai segala macam bentuk kegiatan yang dapat menyalurkan dorongan seksual seseorang. Dalam hubungan antar jenis, bentuk-bentuk kegiatan yang dapat menyalurkan dorongan seksual biasanya melibatkan dua orang yang berbeda jenis kelaminnya. Sedangkan perilaku seks pranikah merupakan perilaku seks yang dilakukan tanpa melalui proses pernikahan yang resmi menurut hukum maupun menurut agama dan kepercayaan masing-masing individu.

Perilaku atau aktivitas seksual diwujudkan dalam bentuk kissing, necking, petting dan in- 
tercourse (Sarwono, 2010). Kissing adalah ciuman yang dilakukan untuk menimbulkan rangsangan seksual, seperti di bibir disertai dengan rabaan pada bagian-bagian sensitif yang dapat menimbulkan rangsangan seksual. Bentuk kissing ini meliputi cium kening, cium pipi, cium bibir.

Necking merupakan rangsangan di sekitar leher ke bawah. Necking ini dapat berupa ciuman di sekitar leher serta pelukan secara mendalam untuk menimbulkan rangsangan.

Petting yaitu perilaku menggesek-gesekkan bagian tubuh yang sensitif, seperti payudara dan organ kelamin. Merupakan langkah yang lebih mendalam dari necking. Ini termasuk merasakan dan mengusap-usap tubuh pasangan termasuk lengan, dada, buah dada, kaki, dan kadang-kadang daerah kemaluan, baik di dalam atau di luar pakaian. Perilaku petting ini juga ditunjukkan dengan perilaku oral seks yaitu melakukan rangsangan dengan mulut pada organ seks pasangannya. Jika melakukan oral seks itu laki-laki, sebutannya adalah cunnilingus, jika yang melakukan oral seks tersebut perempuan, sebutannya adalah fellatio.

Sedangkan definisi intercouse sendiri ialah bersatunya dua orang secara seksual yang dilakukan oleh pasangan pria dan wanita yang ditandai dengan penis pria yang ereksi masuk ke dalam vagina untuk mendapatkan kepuasan seksual. Intercouse juga bisa dalam anal seks yaitu hubungan seksual yang dilakukan dengan memasukkan penis ke dalam anus atau anal.

Sedangkan masturbasi, Tukan (1993: 74) menyatakan bahwa masturbasi merupakan suatu bentuk perilaku seksual yang berasal dari kata Latin yang berarti: "memuaskan diri sendiri." Selanjutnya, kata onani berasal dari nama seseorang, yaitu Onan. Onan tidak melakukan masturbasi seperti yang dipahami masyarakat sekarang, tetapi Onan melakukan senggama terputus atau coitus interruptus, dan namanya dipakai sebagai sinonim untuk masturbasi. Masturbasi atau onani diartikan Tukan sebagai pemenuhan dan pemuasan kebutuhan seksual dengan merangsang alat kelamin sendiri dengan tangan dan atau dengan alat-alat mekanik.

Menurut Fisher (1994: 76-77), masturbasi adalah menyentuh atau menggosok-gosok alat kelamin sendiri dengan macam-macam benda dan mendapatkan rangsangan seksual untuk mendapat kenikmatan, yaitu mencapai puncak (klimaks). Masturbasi biasanya dilakukan pada bagian tubuh yang sensitif, yang berbeda pada masing-masing orang, misalnya puting payudara, paha bagian dalam, dan alat kelamin. Chaplin (2005: 289) menyatakan pula bahwa masturbasi adalah induksi satu keadaan penegangan alat kelamin dan pencapaian orgasme lewat rangsangan dengan tangan atau rangsangan mekanis.

Di bawah ini analisis data responden dipaparkan data dari jawaban responden yang terdiri dari informasi mengenai jenis kelamin dan usia.

Tabel 7. 1 Jenis Kelamin Responden

\begin{tabular}{llll}
\hline No & Jenis Kelamin & $\mathrm{F}$ & $\%$ \\
\hline 1. & Laki-laki & 53 & 53 \\
\hline 2. & Perempuan & 47 & 47 \\
\hline \multicolumn{2}{l}{ Jumlah } & 100 & 100,00 \\
\hline
\end{tabular}

Sumber data: angket bagian I nomer 1 .

Sebagian besar responden berjenis kelamin laki-laki, yaitu sebanyak 53 responden $(53 \%)$. Dan sisanya hampir setengahnya yaitu 47 responden $(47 \%)$ yaitu perempuan. Dalam hal ini tidak ada perbedaan antara jenis kelamin responden, semuanya dianggap sama sebagai responden penelitian. Namun ini menunjukkan paling tidak tingkat keterbukaan mengenai tema penelitian ini lebih dimiliki oleh laki-laki, karena banyak calon responden perempuan yang dimintai mengisi angket kemudian urung mengisi setelah tahu bahwa tema penelitian ini cukup sensitif dan pribadi.

Mahasiswa yang menjadi responden berusia antara 18 tahun, yaitu sebanyak 5 responden $(5 \%)$; berusia 19 tahun yaitu sebanyak 26 responden (26\%); berusia 20 tahun yaitu sebanyak 38 responden (38\%); berusia 21 tahun yaitu sebanyak 20 responden $(20 \%)$; berusia 22 tahun yaitu sebanyak 6 responden $(6 \%)$; berusia 23 tahun yaitu sebanyak 3 responden (3\%); dan diatas 23 tahun yaitu sebanyak 2 responden $(2 \%)$.

Dari data di atas dapat dikatakan bahwa usia yang pada umumnya bisa dijumpai 
disekitar kampus berkisar antara 19-21 tahun jika diakumulasikan menjadi 84 responden (84\%), atau mahasiswa tahun pertama hingga keempat. Memang pada tahun-tahun tersebut seorang mahasiswa mulai dapat menikmati kehidupan kampus ditambah beban perkuliahan yang tinggi dimulai pada semester dua hingga delapan.

\section{Tabel 7. 2 Usia Responden}

\begin{tabular}{llll}
\hline No & Umur & F & $\%$ \\
\hline 1 & 18 tahun & 5 & 5 \\
\hline 2 & 19 tahun & 26 & 26 \\
\hline 3 & 20 tahun & 38 & 38 \\
\hline 4 & 21 tahun & 20 & 20 \\
\hline 5 & 22 tahun & 6 & 6 \\
\hline 6 & 23 tahun & 3 & 3 \\
\hline 7 & $>23$ tahun & 2 & 2 \\
\hline Jumlah & 100 & 100,00 \\
\hline
\end{tabular}

Sumber data: angket bagian I nomer 2.

Pada bagian ini peneliti akan menjabarkan kemudian menganalisis data dari jawaban mengenai: pernyataan pernah atau tidak melakukan aktivitas seksual, bentuk aktivitas seksual yang dilakukan, melibatkan siapa aktivitas seksual yang lakukan, tempat melakukan aktivitas seksual, dan kuantitas aktivitas seksual.

Tabel 7. 3 Pernyataan Pernah atau Tidak Melakukan Aktivitas Seksual

\begin{tabular}{llll}
\hline No & Jenis Pernyataan & $\mathrm{F}$ & $\%$ \\
\hline 1 & Ya & 81 & $81 \%$ \\
\hline 2 & Tidak & 15 & $15 \%$ \\
\hline 3 & Tidak Diisi & 4 & $4 \%$ \\
\hline Jumlah & 100 & 100,00 \\
\hline
\end{tabular}

Sumber data: angket bagian III nomer 1 .

Data menunjukkan bahwa mahasiswa responden yang menyatakan pernah melakukan aktivitas seksual yaitu sebanyak 81 responden (81\%); sedangkan yang menyatakan tidak pernah melakukan aktivitas seksual sebanyak 15 responden (15\%); selebihnya tidak diisi sebanyak 4 responden (4\%).
Berdasarkan data di atas boleh dikatakan bahwa pada umumnya mahasiswa Responden sudah pernah melakukan aktivitas seks sebesar $81 \%$. Hal ini cukup mendukung beberapa penelitian sebelumnya misalnya yang dilakukan oleh Direktorat Remaja dan Perlindungan Hak-hak Reproduksi Badan koordinasi Keluarga Berencana Nasional (BKKBN) sedikitnya $63 \%$ atau 40,95 juta remaja di Indonesia mengaku pernah melakukan hubungan intim sebelum menikah (http://prov.bkkbn.go.id/banten/ news detail.php?nid=83). Kemudian, di kota Bandung sendiri, lebih dari setengah jumlah remaja atau tepatnya 56\% sudah melakukan perilaku seksual intercourse pranikah. Data ini diperoleh berdasarkan survei yang dilakukan oleh PKBI Jabar pada bulan Juni 2008 di setiap kecamatan dengan sampel 100 orang remaja berusia 15-24 (13/08/08. Harian Pagi Tribun Jabar).

Tabel 7. 4 Bentuk Aktivitas Seksual yang Dilakukan

\begin{tabular}{cccc}
\hline No & Jenis Aktivitas & F & $\%$ \\
\hline 1 & Kissing & 29 & $29 \%$ \\
\hline 2 & Necking. & 21 & $21 \%$ \\
\hline 3 & Petting. & 13 & $13 \%$ \\
\hline 4 & Intercourse. & 16 & $16 \%$ \\
\hline 5 & Masturbation. & 10 & $10 \%$ \\
\hline 6 & Tidak Diisi. & 13 & $13 \%$ \\
\hline & Jumlah & 100 & 100,00 \\
\hline
\end{tabular}

Sumber data: angket bagian III nomer 2 .

Berdasarkan data di atas jika dibuat ranking aktivitas seksual terbanyak yang dilakukan oleh mahasiswa Responden yaitu kissing $29 \%$; necking sebesar $21 \%$; intercourse sebesar $16 \%$; petting sebesar $13 \%$; terakhir masturbation sebesar 10\%. Jika di cross-check dengan data Tabel 3 (Pernyataan Pernah atau Tidak Melakukan Aktivitas Seksual) yang mengatakan tidak pernah melakukan aktivitas seksual sebesar $15 \%$ dan tidak diisi $4 \%$ bila dijumlahkan $(15 \%+4 \%)$ menjadi 19\% maka terjadi inkosistensi dengan adanya selisih $6 \%$ pada Tabel 4 (Bentuk Aktivitas Seksual yang Dilakukan). Hal ini dapat dikatakan boleh jadi prosentasi mahasiswa Responden yang pernah melakukan aktivitas seksual bukan $81 \%$ namun lebih besar yaitu $87 \%$ merujuk pada Tabel 4 yang dijumlahkan. 
Tabel 7.5 Melibatkan Siapa Aktivitas Seksual yang Lakukan

\begin{tabular}{llll}
\hline No & Jenis Hubungan & $\mathrm{F}$ & $\%$ \\
\hline 1 & Pacar & 66 & $66 \%$ \\
\hline 2 & Teman & 8 & $8 \%$ \\
\hline 3 & $\begin{array}{l}\text { Pekerja seks komer- } \\
\text { sial (PSK) }\end{array}$ & 2 & $2 \%$ \\
\hline 4 & Lainnya..... & 8 & $8 \%$ \\
\hline 5 & Tidak Diisi & 18 & $18 \%$ \\
\hline Jumlah & 100 & 100,00 \\
\hline
\end{tabular}

Sumber data: angket bagian III nomer 4.

Data di atas menunjukkan aktivitas seksual yang dilakukan mahasiswa Responden yang melibatkan pacar yaitu sebanyak 66 responden $(66 \%)$; teman sebanyak 8 responden (8\%); PSK sebanyak 2 responden (2\%); lainnya sebanyak 8 responden ( $8 \%$ ); dan yang tidak diisi sebanyak 18 responden (18\%).

Berdasarkan data di atas boleh dikatakan bahwa sebagian besar mahasiswa Responden melakukan aktivitas seksual melibatkan pacar mereka sebesar 66\%. Sebagian kecil melibatkan teman $8 \%$, PSK $2 \%$, dan lainnya $8 \%$ yaitu pecun (perempuan cuma-cuma), tetangga atau anak tetangga rumah maupun kontrakan.

Tabel 7. 6 Lokasi Melakukan Aktivitas Seksual

\begin{tabular}{llll}
\hline No & Nama Tempat & F & $\%$ \\
\hline 1 & Rumah & 16 & $16 \%$ \\
\hline 2 & $\begin{array}{l}\text { Tempat kos / kontra- } \\
\text { kan }\end{array}$ & 13 & $13 \%$ \\
\hline 3 & Penginapan / hotel & 10 & $10 \%$ \\
\hline 4 & Kampus & 10 & $10 \%$ \\
\hline 5 & Lainnya ... & 29 & $29 \%$ \\
\hline 6 & TIdak Diisi & 22 & $22 \%$ \\
\hline Jumlah & 100 & 100,00 \\
\hline
\end{tabular}

Sumber data: angket bagian III nomer 5.

Data menunjukkan tempat dimana mahasiswa Responden biasanya melakukan aktivitas seksual di rumah yaitu sebanyak 16 responden (16\%); di tempat kos atau kontrakan sebanyak 13 responden $(13 \%)$; di penginapan / hotel sebanyak 10 responden $(10 \%)$; di kampus sebanyak 10 responden $(10 \%)$; dan tempat lainnya sebanyak 29 responden (29\%), sedangkan yang tidak diisi sebanyak 22 responden (22\%).
Berdasarkan data di atas, rumah menjadi salah satu tempat dimana biasanya aktivitas seks dilakukan. Hal tersebut agak mengejutkan dengan mempertanyakan pengawasan orang tua pada anak-anak mereka. Kemudian kampus juga menjadi salah satu tempat biasanya aktivitas seks berlangsung. Lagi-lagi harus dipertanyakan kebijakan kampus mengenai pengawasan aktivitas mahasiswa-mahasiswi-nya di area kampus. Sedangkan yang mengisi tempat lainnya mereka menulis aktivitas seks biasanya dilakukan di mobil, bioskop, dan pantai atau tempat-tempat rekreasi lainnya.

Tabel 7. 7 Kuantitas Melakukan Aktivitas Seksual

\begin{tabular}{cccc}
\hline No & Kuantitas & $\mathrm{F}$ & $\%$ \\
\hline 1 & $\begin{array}{c}\text { Satu hari dalam satu } \\
\text { minggu. }\end{array}$ & 41 & $41 \%$ \\
\hline 2 & $\begin{array}{c}\text { Dua hari dalam satu } \\
\text { minggu. }\end{array}$ & 11 & $11 \%$ \\
\hline 3 & $\begin{array}{c}\text { Tiga hari dalam satu } \\
\text { minggu. }\end{array}$ & 11 & $11 \%$ \\
\hline 4 & $\begin{array}{c}\text { Empat hari dalam } \\
\text { satu minggu. }\end{array}$ & 5 & $5 \%$ \\
\hline 5 & $\begin{array}{c}\text { Lima hari dalam } \\
\text { satu minggu. }\end{array}$ & 3 & $3 \%$ \\
\hline 6 & $\begin{array}{c}\text { Enam hari dalam } \\
\text { satu minggu. }\end{array}$ & 2 & $2 \%$ \\
\hline 7 & Setiap Hari & 3 & $3 \%$ \\
\hline 8 & Tidak Diisi. & 24 & $24 \%$ \\
\hline & Jumlah & 100 & 100,00 \\
\hline Sulat
\end{tabular}

Sumber data: angket bagian III nomer 6 .

Data menunjukkan, mahasiswa responden melakukan aktivitas seksual minimal satu hari dalam satu minggu yaitu sebanyak 41 responden (41\%); dua hari dalam satu minggu sebanyak 11 responden (11\%); tiga hari dalam satu minggu sebanyak 11 responden (11\%); empat hari dalam satu minggu sebanyak 5 responden (5\%); lima hari dalam satu minggu sebanyak 3 responden (3\%); enam hari dalam satu minggu sebanyak 2 responden (2\%); setiap hari seba- 
nyak 3 responden $(3 \%)$; dan selebihnya tidak diisi sebanyak 24 responden (24\%).

Berdasarkan data di atas jika dibuat ranking berapa hari dalam satu minggu mahasiswa Responden melakukan aktivitas seksual yaitu satu hari sebesar $41 \%$; dua hari sebesar $11 \%$; tiga hari sebesar $11 \%$; empat hari sebesar 5\%; lima hari sebesar 3\%; setiap hari sebesar 3\%; dan terakhir enam hari sebesar $2 \%$.

\section{SIMPULAN DAN SARAN}

Pada umumnya mahasiswa menyatakan pernah melakukan aktivitas seksual. Bentuk aktivitas seksual yang dilakukan adalah kissing, necking, petting, intercourse dan masturbasi. Responden melakukan aktivitas seksual sebagian besar melibatkan pacar, sebagian kecil melibatkan teman, PSK, dan lainnya yaitu "pecun" (perempuan cuma-cuma), tetangga, anak tetangga, induk semang pondokan atau anak induk semang. Rumah menjadi salah satu tempat dimana biasanya aktivitas seks dilakukan selanjutnya tempat kos/kontrakan, kampus, penginapan, di dalam mobil, dan tempat-tempat rekreasi atau hiburan. Hampir setengah dari reponden melakukan aktivitas seksual minimal satu hari dalam seminggu, bahkan sebagian kecil melakukkannya setiap hari.

Berdasarkan beberapa simpulan yang dibuat, terdapat beberapa saran yang bisa diberikan, yaitu tingkat aktivitas seksual mahasiswa yang tinggi (81-87\%) di kalangan mahasiswa di Jatinangor harus mendapatkan perhatian yang serius dari pihak kampus, orang tua dan pemerintah setempat sebelum mengarah pada kehamilan di luar nikah bahkan aborsi atau tindak kejahatan seksual lainnya. Fakta yang luar biasa juga muncul berkaitan dengan tempat-tempat dimana biasanya aktivitas seks dilakukan: rumah, kampus, kontrakan/kos, mobil, bioskop, hotel/penginapan, dan tempat-tempat rekreasi. Pengawasan yang ketat oleh pihak-pihak yang berwenang pada lokasi-lokasi tersebut merupakan hal yang harus segera dilakukan. Pendidikan seks dan kesehatan reproduksi adalah sesuatu yang tidak bisa ditunda lagi untuk dilaksanakan, guna meminimalisir kemungkinan lebih jauh dari hasil perilaku seksual misalnya kehamilan dan aborsi serta mewabahnya penyakit-penyakit seksual.

\section{DAFTAR PUSTAKA}

Ajzen, I. (2005.) Attitudes, Personality, And Behavior. Second Edition. New York: Open University Press.

Arikunto. (1995). Metode Penelititan Deskriptif. Bandung: Tarsito.

Chaplin, J.P. (2005). Kamus Lengkap Psikologi. Jakarta: Raja Grafindo Persada.

Fisher, D.L. (1994). Jalan Keluar dari Jerat Masturbasi. Yogyakarta: CV. Andi Offset.

Rakhmat, Jalaluddin. (1999). Metode Penelitian Komunikasi. Bandung: Remadja Karya CV.

Nanang. (2000). Modul Kesehatan Reproduksi. Bandung: Mitra Citra Remaja.

Notoatmodjo, Soekidjo. (2003). Pendidikan Dan Perilaku Kesehatan. Jakarta: Rineka Cipta.

Santrock, J.W. (2003). Adolescence Perkembangan Remaja. Jakarta: PT. Erlangga.

Sarwono, Sarlito Wirawan. (2010). Psikologi Remaja (Edisi Revisi). Jakarta: PT. Raja Gravido Persada

Supardi, A. (1979). Statistik. Bandung: Fakultas Tarbiah IAIN Sunan Gunung Jati.

Tukan, J.S. (1993). Metode Pendidikan Seks, Perkawinan dan Keluarga. Jakarta: Erlangga.

Ditjen PP\&PL. 2013. Laporan Situasi Perkembangan HIV \& AIDS di Indonesia Tahun 2013 Direktorat Jenderal Pengendalian Penyakit dan Penyehatan Lingkungan. Kementerian Kesehatan RI.

Utomo, Iwu Dwisetyani dan Utomo, Ariane. (2013). Adolescent Pregnancy in Indonesia: A Literature Review. Australian Demographic and Social Research Institute The Australian National University.

Surat Kabar Harian Pagi Kompas: 07/07/2010.

Surat Kabar Harian Pagi Tribun Jabar: 13/08/2008.

http://prov.bkkbn.go.id/banten/news detail. php?nid=83 retreive 15 April 2014.

http://sumedangkab.bps.go.id/publikasi/kecamatan-jatingangor-dalam-angka-2013 retreive 15 April 2014.

http://www.klik-galamedia.com/pembuang-bayi-ternyata-oknum-mahasiswi retrieve 21 Desember 2013

http://www.suaramerdeka.com/v1/index.php/ read/cetak/2013/09/30/238430/Tiap-Tahun-Terjadi-25-Juta-Aborsi- retreive 15 April 2014 